\title{
Relationship between friction force and orthodontic force at the leveling stage using a coated wire
}

\author{
Masaki MURAYAMA ${ }^{1}$, Yasuhiro NAMURA ${ }^{2}$, Takahiko TAMURA ${ }^{2}$, Hiroaki IWAI' ${ }^{1}$, Noriyoshi SHIMIZU ${ }^{2}$ \\ 1- Department of Orthodontics, Nihon University School of Dentistry, Tokyo, Japan. \\ 2- Division of Clinical Research, Dental Research Center and Department of Orthodontics, Nihon University School of Dentistry, Tokyo, Japan. \\ Corresponding address: Yasuhiro Namura - 1-8-13 Kandasurugadai - Chiyoda-ku - Tokyo - 101-8310 - Japan - Phone: +81-3-3219-8105 - Fax. +81-3-3219-8312 \\ e-mail: namura.yasuhiro@nihon-u.ac.jp
}

Submitted: May 7, 2013 - Modification: June 23, 2013 - Accepted: August 23, 2013

\section{ABSTRACT}

\begin{abstract}
$T^{\text {he }}$ he relationship between orthodontic force and friction produced from an archwire and brackets affects the sliding of the wire in the leveling stage. Objective: The purpose of this study was to evaluate the relationship between force and friction in a small esthetic nickel-titanium (Ni-Ti) wire. Material and Methods: Five esthetic wires (three coated and two plated) and two small, plain $\mathrm{Ni}-\mathrm{Ti}$ wires (0.012 and 0.014 inches) were used. We performed a three-point bending test according to ISO 15841 and the drawing test with a dental arch model designed with upper linguoversion of the lateral incisor in the arch (displacements of $0.5,1.0,2.0$ and $3.0 \mathrm{~mm}$ ), and evaluated the relationship between them. Results: Unloading bending forces of all wires at displacements of less than $1.0 \mathrm{~mm}$ were larger than friction forces, but all friction forces at displacements exceeding $2.0 \mathrm{~mm}$ were larger than unloading bending forces. The arch likely expands when displacement from the proximal brackets exceeds $1.0 \mathrm{~mm}$. The friction force of a martensite 0.014 -inch $\mathrm{Ni}-\mathrm{Ti}$ wire was significantly greater than those of the other esthetic and austenitic wires. Conclusions: A wire with the smallest possible friction force should be used in cases with more than $1.0 \mathrm{~mm}$ displacement.
\end{abstract}

Key words: Orthodontics. Friction. Esthetic. Materials.

\section{INTRODUCTION}

An esthetic wire coated with a tooth-colored plastic material, such as a synthetic fluorinecontaining resin or an epoxy resin composed mainly of polytetraflueroethlyene ${ }^{18}$, has been used to satisfy esthetic demands. Several problems involving the wearing or peeling of the outer coatings of coated wires have been identified. Proffit ${ }^{17}$ (2000) described the coat as "undurable". Kusy ${ }^{13}$ (1997) found that coated, colored wires are routinely damaged by mastication forces and the activity of oral enzymes within 3 weeks of their use in vivo. Elayyan, Silikas and Bearn ${ }^{5}$ (2008) reported that surface roughness of coated archwires increased after use in vivo. Kaphoor and Sundareswaran ${ }^{11}$ (2012) reported that the forces of some coated wires were significantly lower than those of uncoated wires. Other authors also encountered difficulties with such coated archwires, claiming that the color tended to change with time and that the coating split during use in the mouth, exposing the underlying metal ${ }^{6}$. In addition, the evaluation of wire properties, such as force and smoothness, would be valuable because the sliding of a wire with problematic surface properties, such as the durability of the coating material, may be inferior to that of an uncoated wire. Some reports have described the influence of wire sliding against a single piece of bracket with soaking solution ${ }^{1}$ and the relationship between the cross-sectional dimensions of the wire and load deflection ${ }^{21}$.

We initially use small wires, such as a 0.012 -inch nickel-titanium ( $\mathrm{Ni}-\mathrm{Ti}$ ) wire, because use of lowfriction brackets is widespread? ${ }^{7}$. In the initial stages of orthodontic treatment, the wire used must produce a continuous force without interference. Although the sliding resistance (interference) of the wire depends on its size as compared to the bracket slot room $^{8}$, the relationship between force and resistance is important because it affects the movement of the teeth. During leveling of dental arches with irregularities, if the force produced by the wire is 


\begin{tabular}{|c|c|c|c|c|}
\hline Abb. & Products & Manufactures & Surface treatment & Wire sizes \\
\hline$A-1$ & Aesthetic nickel titanium wire & TP Orthodontics & $\begin{array}{c}\text { Xylan-coated (only labial } \\
\text { surface) }\end{array}$ & $0.012 "$ and $0.014 "$ \\
\hline A-2 & $\begin{array}{c}\text { Nickel titanium wire cosmetic } \\
\text { arches coated }\end{array}$ & Forestadent & $\begin{array}{l}\text { Polytetrafluoroethylene- } \\
\text { coated }\end{array}$ & $\begin{array}{l}\text { 0.012" (coated 0.014") } \\
0.014 " \text { (coated 0.016") }\end{array}$ \\
\hline A-3 & Tynilloy wire lemon gold & Dentsply-sankin & Gold-plated & $0.012 "$ and $0.014 "$ \\
\hline$A-4$ & Tynilloy wire peach gold & Dentsply-sankin & Gold-plated & $0.012 "$ and $0.014 "$ \\
\hline$A-5$ & Tynilloy wire white & Dentsply-sankin & Fluorpolymer-coated & $\begin{array}{l}0.012 " \text { (coated } 0.013 ") \\
\left.0.014 " \text { (coated } 0.015^{\prime \prime}\right)\end{array}$ \\
\hline $\mathrm{P}-1$ & Reflex wire nickel titanium & TP Orthodontics & $\mathrm{N} / \mathrm{A}$ & $0.012 "$ and $0.014 "$ \\
\hline P-2 & Nitinol classic & 3M Unitek & $\mathrm{N} / \mathrm{A}$ & $0.012 "$ and $0.014 "$ \\
\hline
\end{tabular}

Figure 1- Wires used. The base wires $\mathrm{A}-1$ to $\mathrm{A}-5$ and $\mathrm{P}-1$ were austenitic $\mathrm{Ni}-\mathrm{Ti}$, and $\mathrm{P}-2$ was martensite $\mathrm{Ni}-\mathrm{Ti}$ (Abb.: Abbreviation)

less than the friction resistance, as interference, the dental arch must be expanded until the placement at which the resistance is released is reached. Thus, expansion of the dental arch in an extraction case can lead to poor-quality treatment, such as a prolonged duration. $\mathrm{Ni}-\mathrm{Ti}$ wires are categorized into two types (austenitic and martensite types) according to mechanical properties and fabrication. Although both have excellent springback properties, austenitic $\mathrm{Ni}-\mathrm{Ti}$ wires also have shape memory and superelasticity ${ }^{2,4,15}$. Thus, this issue should be examined using small $\mathrm{Ni}-\mathrm{Ti}$ wires with different mechanical properties, and for plain and coated small wires, because coated wires may have sliding issues. The purpose of this study was to evaluate the relationship between mechanical properties and friction in small esthetic (including plated) $\mathrm{Ni}$ Ti wires using a dental arch model designed with linguoversion of the lateral incisor in the arch and an ISO bending test, and to compare esthetic and unesthetic wires.

\section{MATERIAL AND METHODS}

Five esthetic (three coated and two plated) and two small plain $\mathrm{Ni}-\mathrm{Ti}$ (base sizes of 0.012 and 0.014 inches) wires were used (Figure 1). A three-point bending test was carried out using the end $30 \mathrm{~mm}$ of each archwire. To investigate the relationship between force and deflection in the bending of $\mathrm{Ni}-\mathrm{Ti}$ wires, the three-point bending test was performed according to ISO $15841^{10}$. Briefly, we performed the three-point bending test with an interfulcrum distance of $10 \mathrm{~mm}$, a crosshead speed of $7.5 \mathrm{~mm} /$ min, and a temperature of $36 \pm 1^{\circ} \mathrm{C}$ using a testing machine (5567; Instron, Norwood, MA, USA) because the $\mathrm{Ni}-\mathrm{Ti}$ wire used displayed no linear elastic behavior during unloading at temperatures up to $50^{\circ} \mathrm{C}$. Next, we measured the force-deflection curve of each wire and obtained unloading bending forces at deflections of $3.0,2.0,1.0$, and $0.5 \mathrm{~mm}$ during unloading.

To assess friction resistance between brackets

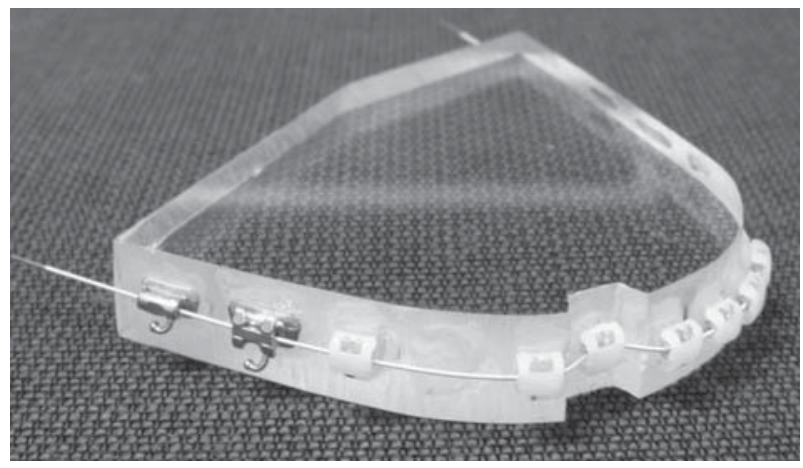

Figure 2-A dental arch-form plate model designed for the linguoversion of the lateral incisor in the arch

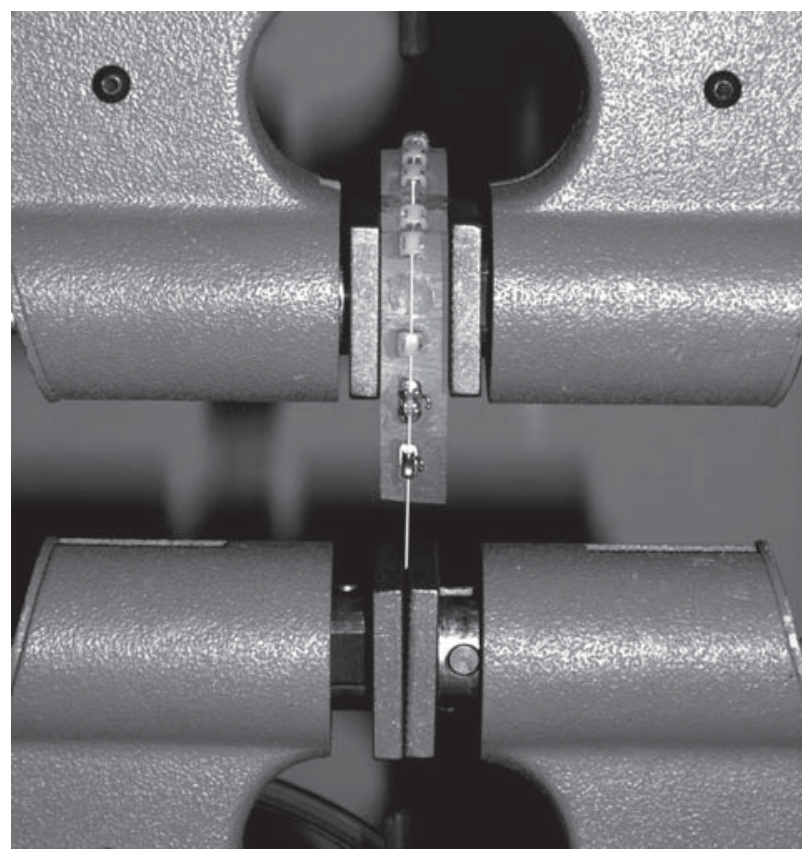

Figure 3- A test of static frictional force. A dental archform plate and the end of an archwire, placed in the arch, are held by the air-chucks of the testing machine 
and wires in the dental arch, static friction force was measured. We placed each wire in low-friction passive-ligating brackets (T-21; Tomy International, Tokyo, Japan; slot size, 0.022 inch; composition, bracket: polyethylene terephthalate etc, slot cap: polyacetal), which were aligned to a dental arch form plate model (Figure 2) with $0.5,1.0,2.0$, or $3.0 \mathrm{~mm}$ displacement at the lateral incisor and the arch-form plate. The brackets and the end of the wire were placed in the air-chucks of the testing machine (5567; Instron; Figure 3). We applied tensile loading under a crosshead speed of $0.5 \mathrm{~mm} /$ min and measured the maximum loading as the static friction force.

Descriptive statistics, including means and standard deviations, were calculated for the unloading bending force and static friction force using statistical analysis software (ver. 16.0; SPSS,
Chicago, IL, USA). Additionally, the Scheffé test and Games-Howell test were used for multiple comparisons among the products. A $P$ value $<0.05$ was considered to indicate statistical significance.

\section{RESULTS}

Bending forces produced from the wires and friction forces at displacements of $3,2,1.0$, and $0.5 \mathrm{~mm}$ during unloading are shown in Tables 1-4. At a displacement of $0.5 \mathrm{~mm}$, unloading bending forces were 27.8-85.6 cN and friction forces were 7.0-50.5 cN. At a displacement of $1.0 \mathrm{~mm}$, unloading bending forces were 42.7-123.2 cN and friction forces were $11.2-93.6 \mathrm{cN}$. Unloading bending forces at a displacement of $2.0 \mathrm{~mm}$ were 50.3-165.4 $\mathrm{cN}$ and friction forces were 96.1-444.9 cN. At a displacement of $3.0 \mathrm{~mm}$, unloading bending forces

Table 1- Unloading bending and friction forces at a displacement of $0.5 \mathrm{~mm}$

S.D.: standard deviation, Sig.: significance. Different letters (Roman type: unloading bending force group; italics: friction force group) indicate a significant difference $(P<0.05)$ within the single-wire-size and identical-force groups

\begin{tabular}{|c|c|c|c|c|c|c|c|c|c|c|c|c|}
\hline & \multicolumn{6}{|c|}{0.012 inch } & \multicolumn{6}{|c|}{0.014 inch } \\
\hline & \multicolumn{3}{|c|}{$\begin{array}{l}\text { Unloading bending force } \\
\text { (cN) }\end{array}$} & \multicolumn{3}{|c|}{ Friction force (cN) } & \multicolumn{3}{|c|}{$\begin{array}{l}\text { Unloading bending force } \\
\text { (cN) }\end{array}$} & \multicolumn{3}{|c|}{ Friction force (cN) } \\
\hline & Mean & S.D. & Sig. & Mean & S.D. & Sig. & Mean & S.D. & Sig. & Mean & S.D. & Sig. \\
\hline$A-1$ & 49.2 & 10.3 & $\begin{array}{l}a, b \\
c, d\end{array}$ & 20.9 & 2 & $a$ & 78.7 & 4.3 & $A$ & 29.4 & 4.4 & $A$ \\
\hline A-2 & 43 & 12.4 & $\begin{array}{l}a, b \\
c, d\end{array}$ & 23 & 7.1 & a & 65.9 & 18.8 & $A, C$ & 25.9 & 6.4 & $A$ \\
\hline A-3 & 32.4 & 1.6 & a & 9.7 & 2.4 & $b$ & 66.3 & 1.1 & $B, C, D$ & 18.8 & 3.1 & $A, C$ \\
\hline A-4 & 48.8 & 2.7 & $\mathrm{~b}$ & 9.1 & 2.9 & $b$ & 79.5 & 3 & A & 20.9 & 6.9 & $A, D$ \\
\hline A-5 & 27.8 & 1.3 & c & 7 & 0.9 & $b$ & 60.7 & 2.7 & $B, C, E$ & 11.4 & 1.5 & $B, C, D$ \\
\hline$P-1$ & 54.1 & 7.5 & $b, e$ & 22.7 & 6.6 & a & 85.6 & 13.4 & $A, D, E$ & 24.6 & 6.3 & $A$ \\
\hline P-2 & 39.7 & 2.8 & $d, e$ & 21.9 & 2.4 & a & 67.6 & 7.3 & $A, D, E$ & 50.5 & 8.3 & $B$ \\
\hline
\end{tabular}

Table 2- Unloading bending and friction forces at a displacement of $1.0 \mathrm{~mm}$

S.D.: standard deviation, Sig.: significance. Different letters (Roman type: unloading bending force group; italics: friction force group) indicate a significant difference $(P<0.05)$ within single-wire-size and identical-force groups

\begin{tabular}{|c|c|c|c|c|c|c|c|c|c|c|c|c|}
\hline & \multicolumn{6}{|c|}{0.012 inch } & \multicolumn{6}{|c|}{0.014 inch } \\
\hline & \multicolumn{3}{|c|}{$\begin{array}{l}\text { Unloading bending force } \\
\text { (cN) }\end{array}$} & \multicolumn{3}{|c|}{ Friction force (cN) } & \multicolumn{3}{|c|}{$\begin{array}{l}\text { Unloading bending force } \\
\text { (cN) }\end{array}$} & \multicolumn{3}{|c|}{ Friction force (cN) } \\
\hline & Mean & S.D. & Sig. & Mean & S.D. & Sig. & Mean & S.D. & Sig. & Mean & S.D. & Sig. \\
\hline$A-1$ & 71.1 & 7.6 & $a, e, f$ & 29.5 & 11.1 & $a, b$ & 88.9 & 5.7 & $A$ & 53.7 & 26.9 & $A, B, D$ \\
\hline A-2 & 54.2 & 3.6 & $b, c$ & 38.6 & 8.8 & a & 86.6 & 5 & A, C & 72.5 & 11.9 & $A, D$ \\
\hline A-3 & 54.8 & 1.3 & $\mathrm{a}, \mathrm{c}$ & 11.2 & 3.7 & $b, c$ & 78.3 & 1.7 & $B, C$ & 31.4 & 7.6 & $B, C$ \\
\hline$A-4$ & 58.5 & 1.8 & $a, c$ & 21.1 & 11 & $a, c, d$ & 95.4 & 1.1 & $A, E$ & 28 & 8.8 & $A, B$ \\
\hline$A-5$ & 42.7 & 0.9 & $d$ & 13.5 & 0.9 & $b, d$ & 78.7 & 2.5 & $B, C$ & 19.7 & 6.4 & $A, B$ \\
\hline P-1 & 78.8 & 1.5 & e & 31.1 & 5.6 & $a$ & 100.9 & 2 & $\mathrm{D}, \mathrm{E}$ & 49.4 & 20.4 & $A, C$ \\
\hline P-2 & 74.2 & 1.9 & $f$ & 43.6 & 13.5 & $a$ & 123.2 & 4.6 & $\mathrm{~F}$ & 93.6 & 13.6 & $D$ \\
\hline
\end{tabular}


Table 3- Unloading bending and friction forces at a displacement of $2.0 \mathrm{~mm}$

S.D.: standard deviation, Sig.: significance. Different letters (Roman type: unloading bending force group; italics: friction force group) indicate a significant difference $(P<0.05)$ within the single-wire-size and identical-force groups

\begin{tabular}{|c|c|c|c|c|c|c|c|c|c|c|c|c|}
\hline & \multicolumn{6}{|c|}{0.012 inch } & \multicolumn{6}{|c|}{0.014 inch } \\
\hline & \multicolumn{3}{|c|}{$\begin{array}{l}\text { Unloading bending force } \\
\qquad(\mathrm{cN})\end{array}$} & \multicolumn{3}{|c|}{ Friction force (cN) } & \multicolumn{3}{|c|}{$\begin{array}{l}\text { Unloading bending force } \\
\text { (cN) }\end{array}$} & \multicolumn{3}{|c|}{ Friction force (cN) } \\
\hline & Mean & S.D. & Sig. & Mean & S.D. & Sig. & Mean & S.D. & Sig. & Mean & S.D. & Sig. \\
\hline$A-1$ & 71.4 & 4.8 & $a, e, f$ & 166 & 26.3 & $a, d$ & 99 & 6.7 & $A, B, C$ & 278.6 & 72.7 & $A, B$ \\
\hline$A-2$ & 58.2 & 1.8 & $b, c$ & 161.6 & 28.3 & $a, d$ & 93.1 & 5.2 & A & 254.2 & 68 & $A, B$ \\
\hline A-3 & 61.8 & 2 & $a, c$ & 96.1 & 20.2 & $b, c$ & 93.5 & 1.9 & A & 250.2 & 16.7 & $A, B$ \\
\hline$A-4$ & 67.6 & 1.2 & e & 122.9 & 23.7 & $a, c$ & 106.6 & 1.4 & B & 218.1 & 27.8 & $A, B$ \\
\hline A-5 & 50.3 & 3.1 & $d$ & 152.1 & 41.2 & $a, c, e$ & 90.8 & 3.6 & $A$ & 285 & 35.9 & $A$ \\
\hline$P-1$ & 79.3 & 1.3 & $f$ & 148.5 & 43.6 & $a, c, f$ & 105 & 2.4 & B & 206 & 28.9 & $B$ \\
\hline $\mathrm{P}-2$ & 96.8 & 2.9 & $g$ & 169.7 & 19.9 & $d, e, f$ & 165.4 & 4.4 & $\mathrm{C}$ & 444.9 & 19.1 & $C$ \\
\hline
\end{tabular}

Table 4- Unloading bending and friction forces at a displacement of $3.0 \mathrm{~mm}$ S.D.: standard deviation, Sig.: significance. Different letters (Roman type: unloading bending force group; italics: friction force group) indicate a significant difference $(P<0.05)$ within the single-wire-size and identical-force groups

\begin{tabular}{|c|c|c|c|c|c|c|c|c|c|c|c|c|}
\hline & \multicolumn{6}{|c|}{0.012 inch } & \multicolumn{6}{|c|}{0.014 inch } \\
\hline & \multicolumn{3}{|c|}{$\begin{array}{l}\text { Unloading bending force } \\
\text { (cN) }\end{array}$} & \multicolumn{3}{|c|}{ Friction force (cN) } & \multicolumn{3}{|c|}{$\begin{array}{l}\text { Unloading bending force } \\
\text { (cN) }\end{array}$} & \multicolumn{3}{|c|}{ Friction force (cN) } \\
\hline & Mean & S.D. & Sig. & Mean & S.D. & Sig. & Mean & S.D. & Sig. & Mean & S.D. & Sig. \\
\hline$A-1$ & 69.4 & 0.8 & $a$ & 259.4 & 0.8 & $a, b$ & 112.3 & 6.1 & $A$ & 599.6 & 125 & $A$ \\
\hline A-2 & 75.4 & 6.1 & a, c & 291.9 & 108.6 & $a, b$ & 118.4 & 10.3 & A & 533.2 & 101.2 & $A$ \\
\hline A-3 & 65.1 & 5.6 & $a, d$ & 164.4 & 47.5 & $a$ & 104.8 & 9.2 & $A$ & 510.8 & 37.8 & $A$ \\
\hline$A-4$ & 70.6 & 2 & a & 256.5 & 21 & $b, c$ & 119.1 & 3.6 & $A$ & 436 & 63 & $A$ \\
\hline$A-5$ & 53.5 & 3.1 & $b, d$ & 276 & 70.8 & $a, c, d$ & 108.2 & 8.8 & $A$ & 548.1 & 61.7 & $A$ \\
\hline P-1 & 82.5 & 2.6 & $c, e$ & 282.2 & 29.2 & $b, d$ & 119.9 & 6.6 & A & 432.8 & 47.1 & $A$ \\
\hline$P-2$ & 90 & 3.2 & $f$ & 205.2 & 23.5 & $a$ & 164.5 & 3.5 & B & 950.7 & 101.6 & $B$ \\
\hline
\end{tabular}

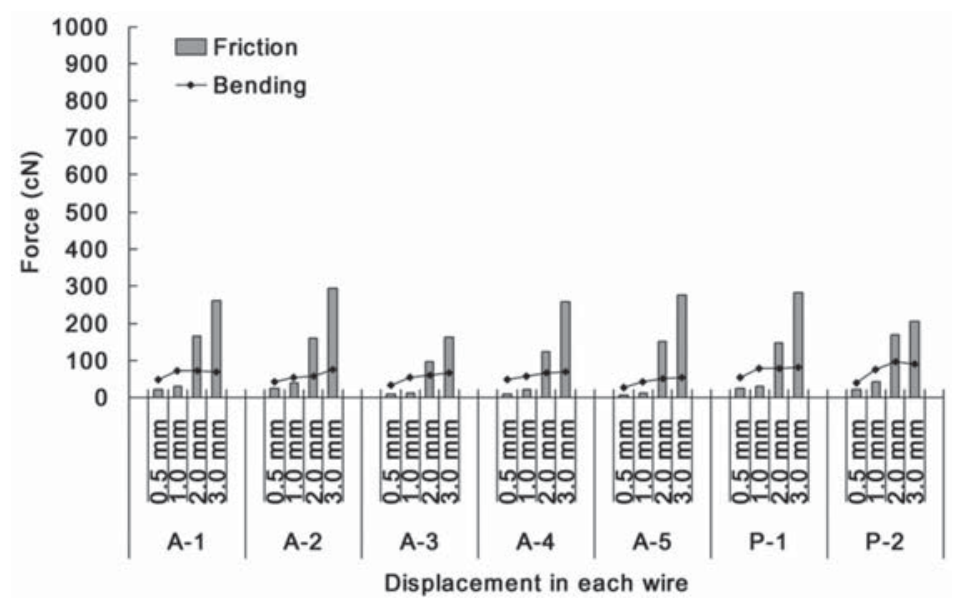

Figure 4- Relationships between unloading bending and friction forces for 0.012 -inch wires. Unloading bending forces at 0.5 and $1.0 \mathrm{~mm}$ were larger than friction forces, but all friction forces at displacements exceeding $2.0 \mathrm{~mm}$ were larger than unloading bending forces 


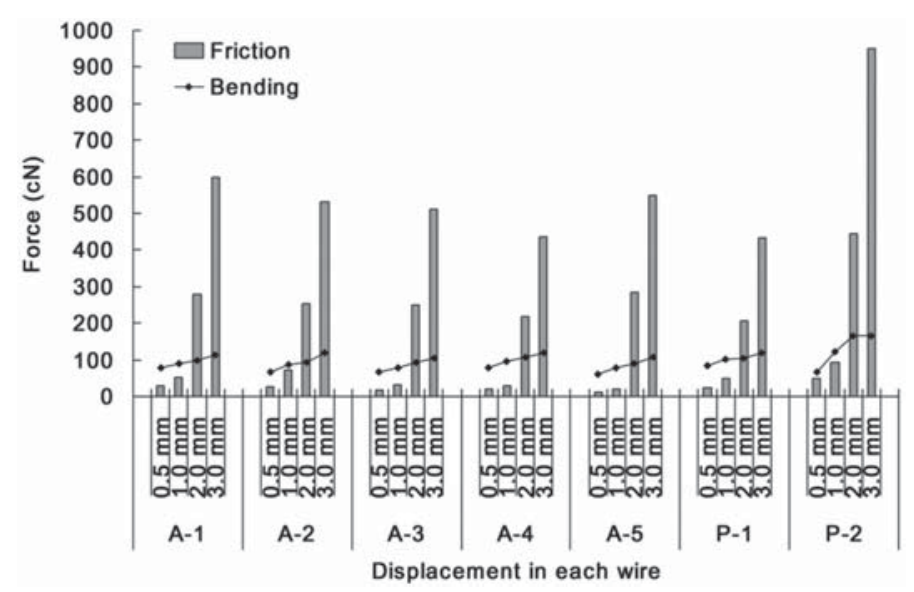

Figure 5- Relationships between unloading bending and friction forces for 0.014 -inch wires

were $53.5-164.5 \mathrm{cN}$ and friction forces were 164.4$950.7 \mathrm{cN}$. Unloading bending and friction forces in each wire, except the 0.014 -inch P-2 wire, did not differ significantly.

The relationships between unloading bending and friction forces for each wire size are shown in Figures 4 and 5. For 0.012- and 0.014-inch wires, all unloading bending forces at 0.5 and $1.0 \mathrm{~mm}$ were larger than friction forces. However, all friction forces at displacements exceeding $2.0 \mathrm{~mm}$ were larger than the unloading bending forces.

\section{DISCUSSION}

At the leveling stage, tooth movement behavior depends on the force produced by the sliding wire and the friction resisting it. In this experiment, the friction force at displacements exceeding $2.0 \mathrm{~mm}$ was larger than the force caused by the wire. That is, teeth are likely to move with the expansion of the dental arch up to a displacement of $1.0 \mathrm{~mm}$. Resistance to sliding has been reported to be slightly greater in the wet state than in the dry state ${ }^{14,23}$. Even if our experiments were performed in the wet state, the relationship should not differ because most friction forces at displacements exceeding 2.0 $\mathrm{mm}$ were markedly larger than unloading bending forces.

Regarding the friction force, many studies have reported the use of experimental models to measure the force of a wire drawn from a bracket ${ }^{3,19,22,24}$. On the other hand, Henao and Kusy ${ }^{8}$ (2004) used a lower typodont malocclusion model with Damon brackets, and reported friction forces of 250-675 cN with a 0.014-inch Ni-Ti wire. Kim, Kim and Baek ${ }^{12}$ (2008) reported that the static friction force of a 0.014-inch austenitic $\mathrm{Ni}-\mathrm{Ti}$ wire was 89.5-2249.0 $\mathrm{CN}$ in a mandibular typodont with $0-3.0 \mathrm{~mm}$ tooth displacement, identical to that used in this study. However, Kim, Kim and Baek ${ }^{12}$ (2008) used a mandibular typodont with lateral incisors that could be displaced lingually. In our experiment, friction forces with the 0.014-inch wire were 11.4-950.7 $\mathrm{cN}$. Thus, if our dental arch model had bilateral tooth displacement, the friction force would be approximately doubled, although the ability to determine the actual friction force is limited in many cases by the simplicity of the model.

Regarding the experimental model, we used a mandibular dental arch that was placed in passive self-ligating brackets to measure friction force. The interfulcrum distance, which is standardized to $10.0 \mathrm{~mm}$ according to ISO $15841^{10}$, matches the interbracket distance in mandibular anterior teeth. Kim, Kim and Baek ${ }^{12}$ (2008) and Henao and Kusy ${ }^{8,9}$ (2004, 2005) reported friction forces obtained with bimaxillary models. Although friction force depends on the degree of tooth displacement and the brackets used, the force in the maxillary arch must be smaller than that in the mandibular arch because the interbracket distance in the mandible is shorter. However, additional experiments are needed to understand the relationship between the maxillary dental arch and friction resistance because the force produced by the wire must also be smaller.

With regard to the relationship between periodontal tissue and orthodontic force, Schwartz ${ }^{20}$ (1932) reported that a safe force for tooth movement was $20-26 \mathrm{~g} / \mathrm{cm}^{2}$. Using a rat experiment model, Noda, et al. ${ }^{16}$ (2000) found that the optimal force corresponding to a human premolar was $41.4 \mathrm{~g}$. In this experiment, the smallest unloading bending force produced by the wire was $27.8 \mathrm{cN}$. The force produced from a wire in the three-point bending test is translated as reciprocal action. Because the force that reaches the teeth becomes half of the unloading bending force, the forces of all 0.012 -inch wires at a displacement of $0.5 \mathrm{~mm}$ and those of some $0.012-$ inch wires at a displacement of $1.0 \mathrm{~mm}$ were likely of doubtful use for optimal tooth movement.

In product comparisons, no significant difference in unloading bending or friction force was detected between esthetic and $\mathrm{P}-1$ wires or among esthetic wires. However, significant differences in force- 
deflection curves were detected between plain P-1 and P-2 Ni-Ti wires. The P-2 wire (Nitinol classic) is a stabilized (work-hardened) martensitic $\mathrm{Ni}-\mathrm{Ti}$ wire, whereas the $\mathrm{P}-1$ and other wires have curves that convey superelasticity, resulting in an almost even force during unloading ${ }^{2,4,15}$. Thorstenson and Kusy $^{25}$ (2002) reported that the regression lines in the sliding of a stabilized martensitic $\mathrm{Ni}-\mathrm{Ti}$ wire differed from those of active austenitic $\mathrm{Ni}$-Ti wires. In our study, at a displacement of $3.0 \mathrm{~mm}$, the ratio between the friction and unloading bending forces of a 0.014 -inch P-2 wire was the largest among wires, and the friction force was approximately 5.8-fold larger than the unloading bending force. Thus, the surface treatment of the wire used is likely unimportant for austenitic $\mathrm{Ni}$-Ti wires. Furthermore, the stabilized martensitic Ni-Ti wire, which exhibited a larger ratio, is not likely to be superior to other wires with respect to the relationship between force and friction, at least within the limitations of this experiment.

\section{CONCLUSIONS}

Within the limitations of this study, the following conclusions were reached:

Because the friction force at displacements exceeding $2.0 \mathrm{~mm}$ is larger than the force produced by the wire, teeth are likely to move with the expansion of the dental arch up to a displacement of $1.0 \mathrm{~mm}$.

No significant difference in unloading bending or friction force was detected between esthetic and austenitic plain Ni-Ti wires. The surface treatment of an austenitic Ni-Ti wire is apparently unimportant.

The ratio between friction and unloading bending forces was smaller for austenitic $\mathrm{Ni}$-Ti wires than for martensitic $\mathrm{Ni}$-Ti wires; thus, austenitic $\mathrm{Ni}-\mathrm{Ti}$ wires are likely more appropriate for clinical use.

\section{ACKNOWLEDGMENTS}

This work was supported, in part, by a grant from the Dental Research Center, Nihon University School of Dentistry.

\section{REFERENCES}

1- Bandeira AM, Santos MP, Pulitini G, Elias CN, Costa MF. Influence of thermal or chemical degradation on the frictional force of an experimental coated NiTi wire. Angle Orthod. 2011;81:484-9. 2- Bradley TG, Brantley WA, Culbertson BM. Differential scanning calorimetry (DSC) analyses of superelastic and non-superelastic nickel-titanium orthodontic wires. Am J Orthod Dentofacial Orthop. 1996;109:589-97.

3- Burrow SJ. Friction and resistance to sliding in orthodontics: a critical review. Am J Orthod Dentofacial Orthop. 2009;135:442-7. 4- Burstone CJ, Qin B, Morton JY. Chinese NiTi wire - a new orthodontic alloy. Am J Orthod. 1985;87:445-52.
5- Elayyan F, Silikas N, Bearn D. Ex vivo surface and mechanical properties of coated orthodontic archwires. Eur J Orthod. 2008;30:661-7.

6- Elayyan F, Silikas N, Bearn D. Mechanical properties of coated superelastic archwires in conventional and self-ligating orthodontic brackets. Am J Orthod Dentofacial Orthop. 2010;137:213-7.

7- Harradine N. Self-ligating brackets; theory, practice and evidence. In: Graber TM, Vanarsdall RL, Vig KW Jr (ed.). Orthodontics: current principles techniques. $5^{\text {th }}$ edition. St Louis: Elsevier Mosby; 2011. p.581-614.

8- Henao SP, Kusy RP. Evaluation of the frictional resistance of conventional and self-ligating bracket designs using standardized archwires and dental typodonts. Angle Orthod. 2004;74:202-11. 9- Henao SP, Kusy RP. Frictional evaluations of dental typodont models using four self-ligating designs and a conventional design. Angle Orthod. 2005;75(1):75-85.

10- International Organization for Standardization. ISO 15841: Dentistry - wires for use in orthodontics. Geneva: ISO; 2006.

11- Kaphoor AA, Sundareswaran S. Aesthetic nickel titanium wires - how much do they deliver? Eur J Orthod. 2012;34:603-9. 12- Kim TK, Kim KD, Baek SH. Comparison of frictional forces during the initial leveling stage in various combinations of selfligating brackets and archwires with a custom-designed typodont system. Am J Orthod Dentofacial Orthop. 2008;133:187.e15-24. 13- Kusy RP. A review of contemporary archwires: their properties and characteristics. Angle Orthod. 1997;67:197-207.

14- Kusy RP, Whitley JQ. Resistance to sliding of orthodontic appliances in the dry and wet states: influence of archwire alloy, interbracket distance, and bracket engagement. J Biomed Mater Res. 2000;52:797-811.

15- Miura F, Mogi M, Ohura Y, Hamanaka H. The super-elastic property of the Japanese NiTi alloy wire for use in orthodontics. Am J Orthod Dentofacial Orthop. 1986;90:1-10.

16- Noda K, Yoshii T, Nakamura Y, Kuwahara Y. The assessment of optimal orthodontic force in various tooth movements: comparisons of tooth movement, root resorption, and degenerating tissue in tipping movement. Orthod Waves. 2000;59:329-41.

17- Proffit W. Contemporary orthodontics. St Louis: Mosby; 2000. 18- Ramadan AA. Removing hepatitis C virus from polytetrafluoroethylene-coated orthodontic archwires and other dental instruments. East Mediterr Health J. 2003;9:274-8.

19- Reznikov N, Har-Zion G, Barkana I, Abed Y, Redlich M. Measurement of friction forces between stainless steel wires and "reduced-friction" self-ligating brackets. Am J Orthod Dentofacial Orthop. 2010;138:330-8.

20- Schwartz AM. Tissue changes incidental to orthodontic tooth movement. Int J Orthod. 1932;18:331-52.

21- Silva DL, Mattos CT, Sant' Anna EF, Ruellas AC, Elias CN. Cross-section dimensions and mechanical properties of esthetic orthodontic coated archwires. Am J Orthod Dentofacial Orthop. 2013;143(4 Suppl):S85-91.

22- Stefanos S, Secchi AG, Coby G, Tanna N, Mante FK. Friction between various self-ligating brackets and archwire couples during sliding mechanics. Am J Orthod Dentofacial Orthop. 2010;138:463-7.

23- Thorstenson GA, Kusy RP. Resistance to sliding of self-ligating brackets versus conventional stainless steel twin brackets with second-order angulation in the dry and wet (saliva) states. Am J Orthod Dentofacial Orthop. 2001;120:361-70.

24- Thorstenson GA, Kusy RP. Comparison of resistance to sliding between different self-ligating brackets with second-order angulation in the dry and saliva states. Am J Orthod Dentofacial Orthop. 2002;121:472-82.

25- Thorstenson GA, Kusy RP. Effect of archwire size and material on the resistance to sliding of self-ligating brackets with secondorder angulation in the dry state. Am J Orthod Dentofacial Orthop. 2002;122:295-305. 